\title{
Effect of solid-state fermented and enzyme-supplemented lupins on performance and ileal amino acid digestibility in broiler chickens
}

\author{
Oladapo Oluwaseye Olukomaiya (D)A,D , Liyi Pan ${ }^{\mathrm{C}}$, Dagong Zhang ${ }^{\mathrm{C}}$, Ram Mereddy ${ }^{\mathrm{B}}$, \\ Yasmina Sultanbawa (D) A and Xiuhua $\mathrm{Li}$ (D) \\ ${ }^{A}$ Centre for Nutrition and Food Sciences, Queensland Alliance for Agriculture and Food Innovation (QAAFI), \\ The University of Queensland, Coopers Plains, Brisbane, Qld 4108, Australia. \\ ${ }^{B}$ Queensland Department of Agriculture and Fisheries, Coopers Plains, Brisbane, Qld 4108, Australia. \\ CPoultry Science Unit, School of Agriculture and Food Sciences, The University of Queensland, \\ Gatton, Qld 4343, Australia. \\ DCorresponding author. Email: o.olukomaiya@uqconnect.edu.au
}

\begin{abstract}
Context. The importance of lupin in animal nutrition has increased over the years due to its moderate protein content and relative availability. Low inclusion rate in broiler diet has been associated with the presence of antinutritional factors. The established beneficial effect of fermentation as a processing strategy and dietary enzyme use in improving the nutritional value of legumes such as lupins, thus, necessitated this study.

Aims. This study determined the effect of solid-state fermented lupin (SSFLP) and enzyme-supplemented lupin (LP) on the performance and ileal amino acid digestibility in broiler chickens.

Methods. In Experiment 1 (performance trial), a total of 300 day-old Ross 308 male broiler chicks were distributed into six dietary treatments, with five replicates of 10 birds each. Diet 1 was based on a corn-soybean meal (SBM), Diets 2 and 3 contained $250 \mathrm{~g} / \mathrm{kg}$ LP and $250 \mathrm{~g} / \mathrm{kg}$ SSFLP respectively. Diet 4 contained $250 \mathrm{~g} / \mathrm{kg} \mathrm{LP}+$ phytase (PHY). Diet 5 contained $250 \mathrm{~g} / \mathrm{kg} \mathrm{LP}+$ xylanase (XYL). Diet 6 contained $250 \mathrm{~g} / \mathrm{kg} \mathrm{LP}+$ PHY + XYL. PHY at 500 phytase units (FTU) $/ \mathrm{kg}$ and XYL at 1000 units/kg were added to the respective diets. In Experiment 2 (digestibility trial), a total of 240 21-day-old Ross 308 male broiler chicks was assigned to six dietary treatments with five replicate cages of eight birds each. Diet 1 was based on SBM, Diets 2 and 3 contained $650 \mathrm{~g} / \mathrm{kg} \mathrm{LP}$ and $650 \mathrm{~g} / \mathrm{kg}$ SSFLP respectively. Diet 4 contained $650 \mathrm{~g} / \mathrm{kg}$ LP + PHY. Diet 5 contained $650 \mathrm{~g} / \mathrm{kg} \mathrm{LP}+$ XYL. Diet 6 contained $650 \mathrm{~g} / \mathrm{kg} \mathrm{LP}+\mathrm{PHY}+\mathrm{XYL}$.

Key results. Dietary inclusion of SBM and LP + PHY enhanced broiler performance from 1 to 21 days. PHYsupplemented LP diet improved birds' bodyweight gain and feed intake compared with the rest of the LP diets. Dietary inclusion of LP + PHY + XYL improved the apparent ileal digestibility (AID) of some amino acids (AA). SSF of LP had no effect on the AA contents, lowered AA digestibility and depressed weight gain in the birds. Although SSFLP diet did not improve performance, it effectively increased phosphorus (P) retention in broiler chickens. Feeding SSFLP and enzyme-supplemented LP diets enhanced the AID of calcium and P, as well as calcium retention.

Conclusions. Adding supplemental PHY to LP diet enhanced broiler performance, as indicated by the BWG and FI of these birds, which were significantly higher than those of birds fed on other LP-based diets and comparable with those of birds fed on the SBM diet from 1 to 21 days. Although the SSFLP diet did not improve broiler performance, it was effective in increasing P retention when compared with LP diets. The inclusion of LP + PHY + XYL diet improved the AID of amino acids.

Implications. SSFLP is a promising feed ingredient and can have a potential application in feed formulation. However, further studies are still needed to be able to clearly understand its effect at a high inclusion level on the performance and ileal amino acid digestibility in broiler chickens. The development of cocktail inoculants to target all ANFs in lupins will definitely open a new window for the poultry feed industry.
\end{abstract}

Keywords: digestibility, lupins, nutritive evaluation, poultry nutrition, proteins.

Received 13 February 2021, accepted 6 April 2021, published online 13 May 2021 


\section{Introduction}

Soybean meal (SBM) is the most conventionally used plant protein source in poultry diets. Over-dependence on SBM in poultry feed has posed some economic problems associated with a reduced supply of the commodity, increase in price and competition for food and feed purposes (Zaworska et al. 2017; Olukomaiya et al. 2019c, 2020a). Thus, there is a need to explore alternative sources of protein for poultry feed. In recent times, interest in lupin (LP) as a cost-effective feed ingredient for poultry diet has increased due to its moderate protein content. However, the presence of anti-nutritional factors (ANFs), such as non-starch polysaccharides, fibre, phytic acid and the carbohydrate structure of LP, has been reported to have adverse effects on performance, thereby, limiting a high inclusion rate of LP in non-ruminant diets (Jezierny et al. 2010; Kim et al. 2011; Kasprowicz-Potocka et al. 2015; Zaworska et al. 2017). Thus, overcoming the ANFs of LP and improving the utilisation of nutrients in LP has attracted researchers' attention.

Different strategies and processing methods have been attempted to improve the nutritional value of LP for poultry diets, such as autoclaving, dehulling (Olkowski et al. 2001; Lee et al. 2016; Mera-Zúñiga et al. 2019), use of commercial feed enzymes (Lee et al. 2016; Mera-Zúñiga et al. 2019) and fermentation (Zaworska et al. 2017). Exogenous enzymes have been routinely used in poultry diets. Walters et al. (2019) and Al-Harthi et al. (2020) previously fed phytase at a conventional level of 500 phytase units (FTU)/kg, and the degrading of phytates by phytase supports the release of phosphorus (P), minerals, proteins, amino acids and starch (Chaves et al. 2020). Dietary inclusion of phytase improved feed consumption, bodyweight and feed conversion ratio, reduced mortality and enhanced protein efficiency of broiler chickens (Kong and Adeola 2011; Walters et al. 2019). Ghayour-Najafabadi et al. (2018) also fed xylanase at a conventional level of 1000 units (U)/kg. Exogenous xylanase helps to degrade non-starch polysaccharides in feed ingredients, thereby improving nutrient digestibility and the performance of broiler chickens (Selle et al. 2009). Most of the strategies can reduce ANFs, but SSF may be more promising in effectively reducing ANFs, improving nutritional value, minimising protein loss, reducing environmental pollution, and cheaper to use (Vig and Walia 2001; Shi et al. 2015).

Solid-state fermentation (SSF) has a long history of use in the food and fermentation industries (Soccol et al. 2017; Olukomaiya et al. 2019a, 2019b, 2019c, 2019d; Olukomaiya et al. 2020a, 2020b, 2020c). The beneficial effects of SSF in improving the nutritional quality of food and feed products have been previously documented (Soccol et al. 2017; Olukomaiya et al. 2019a, 2019b, 2021). In the study of Kasprowicz-Potocka et al. (2015), fermentation of LP seeds with Candida utilis increased the crude protein (CP) content and reduced phytate and oligosaccharide content. Zaworska et al. (2016) also found that fermentation of LP with Saccharomyces cerevisiae and commercial multibacterial preparation (Enterococcus faecium, Lactobacillus plantarum, Lactobacillus buchneri and Lactobacillus casei) induced small changes in $\mathrm{CP}$, ash, fat, total alkaloids and phytate P concentrations; in contrast, it removed oligosaccharides, remarkably reduced true protein and increased crude fibre, neutral detergent fibre (NDF) and acid detergent fibre (ADF) contents. In a later study, Zaworska et al. (2017) demonstrated that LP fermentation improved the contents of CP, fibre, fat, ash and most of the analysed amino acids and decreased the raffinose family oligosaccharides and phytic acid contents.

Furthermore, Kasprowicz-Potocka et al. (2015) found that feeding fermented LPs to rats positively affected protein digestibility of the feed, body mass gain and protein efficiency of the rats. Zaworska et al. (2016) also fed Wistar rats with fermented LPs and observed that the apparent total tract digestibility of dietary protein was higher in rats fed fermented LPs than in those fed raw LP diet. Zaworska et al. (2017) studied the influence of fermented LP on ileal digestibility and microbiota in growing pigs. The authors stated that feeding fermented LPs had a positive impact on the apparent ileal digestibility (AID) of CP and amino acids such as methionine, cysteine, isoleucine, leucine, phenylalanine and valine. To the best of our knowledge, no study has previously investigated the effect of SSFLP on performance and ileal amino acid digestibility in broiler chickens. Therefore, the objective of the present study was to determine the effect of solid-state fermented and enzymesupplemented LPs on performance and ileal amino acid digestibility in broiler chickens.

\section{Materials and methods}

All experimental procedures used in this study were approved by the Animal Ethics Committee of the University of Queensland (AEC Approval number: SAFS/274/18). Health and animal husbandry practices complied with the Australian Code of Practice for the Care and Use of Animals for Scientific Purposes issued by the Australian Bureau of Animal Health (National Health and Medical Research Council 1990).

\section{Preparation of SSFLP and enzyme sources}

Lyophilised culture of Aspergillus ficuum (ATCC 66876) was purchased from the American Type Culture Collection (ATCC, Manassas, VA, USA). Cracked LPs (Lupinus angustifolius L.) were purchased from a commercial feed mill (Allora Grain and Milling (AGM), Queensland, Australia). Solid-state fermentation of LP was conducted according to a previously described method (Olukomaiya et al. 2020a). Moisture content of the substrate was optimised at $45 \%$ using reverse osmosis water and substrate was sterilised by autoclaving at $121^{\circ} \mathrm{C}$ for $15 \mathrm{~min}$. After cooling to room temperature, the substrate was inoculated with spore suspension of $A$. ficuum $\left(10^{7}\right.$ spores $\left./ \mathrm{mL}\right)$. Then, the mixture was incubated at $30^{\circ} \mathrm{C}$ for 7 days. The SSFLP was oven-dried for $48 \mathrm{~h}$, cooled, ground to pass through a $1.5 \mathrm{~mm}$ sieve and stored at $4^{\circ} \mathrm{C}$ before dietary inclusion. LP and SSFLP samples were analysed for dry matter, $\mathrm{CP}$, crude fat, crude ash and starch according to standard methods (AOAC 2000). Soluble carbohydrate (glucose) was measured by enzymatic method (Karkalas 1985). Most of the ingredients (in ground form) were purchased from local commercial suppliers in 
Queensland, Australia. The enzymes used were phytase (AXTRA ${ }^{\circledR}$ PHY TPT 10000; (thermo-stable powder) sourced from Buttiauxella spp. and expressed in Trichoderma reesei; Danisco Animal Nutrition, DuPont Industrial Biosciences, Marlborough, UK) and xylanase (AXTRA ${ }^{\circledR}$ XB 201 TPT; a combination of xylanase (with enzyme activity: $12200 \mathrm{U} / \mathrm{g}$ ) and betaglucanase expressed in Trichoderma reesei (with enzyme activity: $1520 \mathrm{U} / \mathrm{g}$ ); Danisco Animal Nutrition, DuPont Industrial Biosciences, Marlborough, UK) supplied by Feedworks Australia.

\section{Experiment 1: performance trial}

In total, 300 day-old Ross 308 male broiler chicks with initial average bodyweight of $38.3 \pm 0.07 \mathrm{~g}$ were obtained from a commercial hatchery (Goulburn, New South Wales, Australia). The experiment had six dietary treatments with five replicate pens per treatment (10 birds per replicate pen $)$ in a completely randomised design. The six experimental diets included the following: Diet 1 was based on corn-SBM, as a reference, and Diets 2 and 3 contained $250 \mathrm{~g} / \mathrm{kg} \mathrm{LP}$ and $250 \mathrm{~g} / \mathrm{kg}$ SSFLP respectively. Diet 4 contained $250 \mathrm{~g} / \mathrm{kg} \mathrm{LP}$ supplemented with $500 \mathrm{FTU} / \mathrm{kg}$ phytase (PHY). Diet 5 contained $250 \mathrm{~g} / \mathrm{kg}$ LP supplemented with $1000 \mathrm{U} / \mathrm{kg}$ xylanase (XYL). Diet 6 contained $250 \quad \mathrm{~g} / \mathrm{kg} \quad \mathrm{LP}$ supplemented with a combination of $500 \mathrm{FTU} / \mathrm{kg} \mathrm{PHY}$ and $1000 \mathrm{U} / \mathrm{kg}$ XYL. The ingredients and nutrient composition of experimental diets are shown in Table 1. Feed and clean water were provided ad libitum throughout the trial. The bedding material used for pen floors was fresh wood shavings. The initial temperature was maintained at $32^{\circ} \mathrm{C}$ and then gradually decreased by $3^{\circ} \mathrm{C}$ every week. Lighting was provided for $24 \mathrm{~h}$ from 1 to 21 days. The trial was conducted for 21 days. At 7, 14 and 21 days, birds and feed were weighed to measure the performance parameters such as bodyweight gain (BWG), feed

Table 1. Ingredient composition of experimental diets ( $\mathrm{g} / \mathrm{kg}$ as-fed basis; Experiment 1$)$ SBM, soybean meal; LP, lupin; SSFLP, solid-state fermented lupin

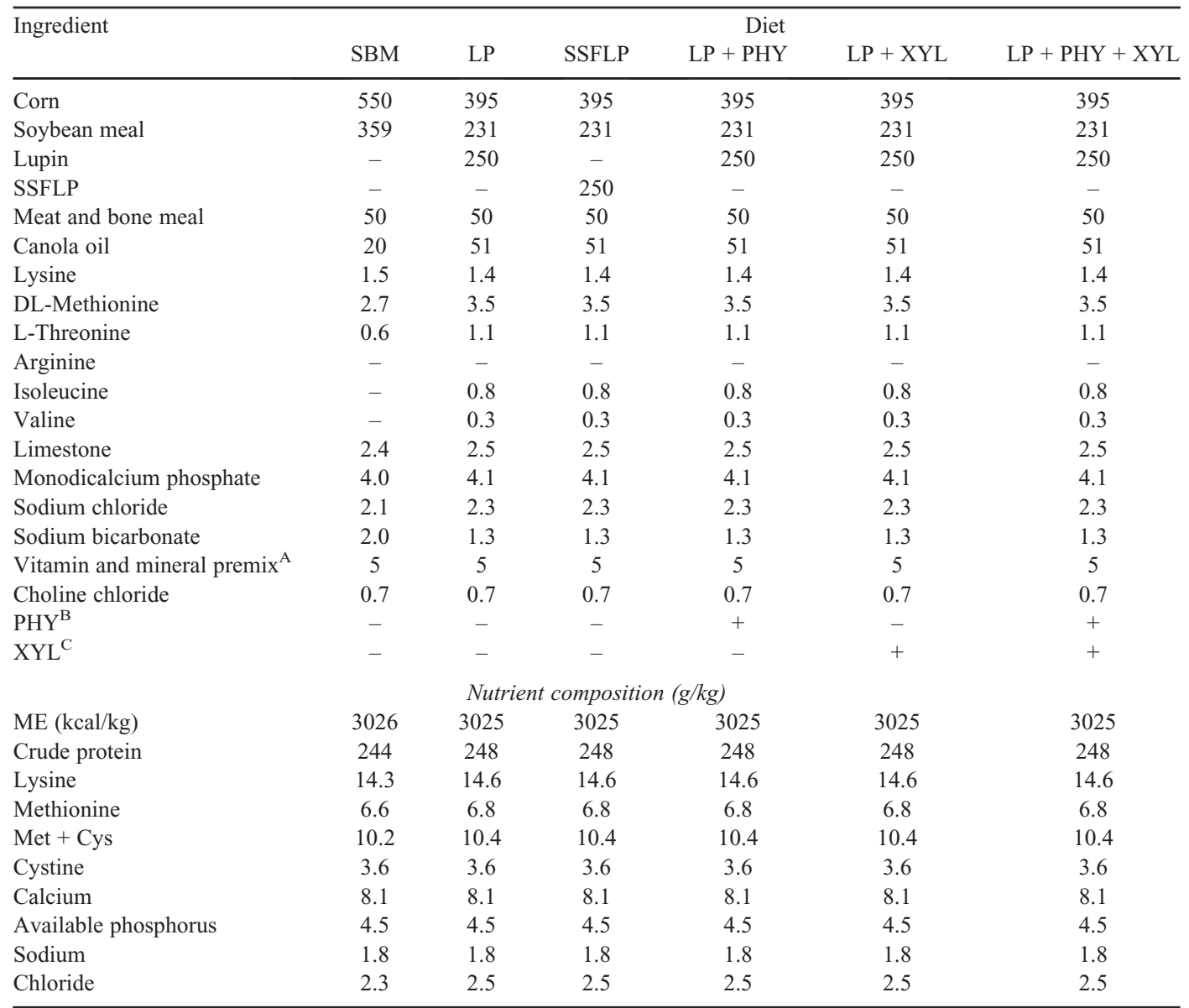

${ }^{\mathrm{A}}$ Each $2 \mathrm{~kg}$ contains the following: vitamin A, 10 milli international units (MIU); vitamin D3, $2.5 \mathrm{MIU}$; vitamin E, $30 \mathrm{~g}$; vitamin $\mathrm{K} 3,2 \mathrm{~g}$; vitamin B1, $1.5 \mathrm{~g}$; vitamin B2, $8 \mathrm{~g}$; vitamin B6, $4 \mathrm{~g}$; vitamin B12, $20 \mathrm{mg}$; vitamin B5, $14 \mathrm{~g}$; vitamin B9, 2 g; vitamin B3, $45 \mathrm{~g}$; vitamin H, $135 \mathrm{mg}$; cobalt, $20 \mathrm{mg}$; copper, $6 \mathrm{~g}$; iron, $50 \mathrm{~g}$; iodine, $750 \mathrm{mg}$; manganese, $75 \mathrm{~g}$; molybdenum, $1 \mathrm{~g}$; selenium, $150 \mathrm{mg}$; zinc, $60 \mathrm{~g}$.

${ }^{B} \mathrm{PHY}$ : phytase added at $500 \mathrm{FTU} / \mathrm{kg}$.

${ }^{\mathrm{C}} \mathrm{XYL}$ : xylanase added at $1000 \mathrm{U} / \mathrm{kg}$. 
intake (FI) and feed conversion ratio (FCR). Mortality in each replicate pen was recorded daily as it occurred, and corrections on BWG, FI and FCR were made accordingly.

\section{Experiment 2: apparent metabolisable energy and amino acid digestibility assay}

In total, 240 21-day-old Ross 308 male broiler chicks were used for the digestibility study. The experiment had six dietary treatments with five replicate cages per treatment (eight birds per replicate cage) in a completely randomised design. Dietary protein in the assay diets was supplied solely by the test ingredients (Bryden et al. 2009; Olukomaiya et al. 2021). The chicks were arranged in cages $(90 \times 75 \times 45 \mathrm{~cm})$, which had a linear feeder in the front and a nipple drinker at the back, in an environmentally controlled room. The six experimental diets included the following: Diet 1 was based on SBM, as a reference; Diets 2 and 3 contained $650 \mathrm{~g} / \mathrm{kg} \mathrm{LP}$ and $650 \mathrm{~g} / \mathrm{kg}$ SSFLP respectively; Diet 4 contained $650 \mathrm{~g} / \mathrm{kg}$ LP supplemented with $500 \mathrm{FTU} / \mathrm{kg}$ PHY; Diet 5 contained $650 \mathrm{~g} / \mathrm{kg}$ LP supplemented with $1000 \mathrm{U} / \mathrm{kg}$ XYL; and Diet 6 contained $650 \mathrm{~g} / \mathrm{kg}$ LP supplemented with a combination of $500 \mathrm{FTU} / \mathrm{kg}$ PHY and $1000 \mathrm{U} / \mathrm{kg}$ XYL. The composition of the diets used in the amino acid digestibility assay is presented in Table 2. The assay diets were offered ad libitum for 4 days, and water was available at all times. Celite ${ }^{\circledR}$ (Celite Corporation, Lompoc, CA, USA), a source of acid-insoluble ash (AIA) was added to all diets at $20 \mathrm{~g} / \mathrm{kg}$ as an indigestible marker. The representative excreta samples were collected in the last two consecutive days, and care was taken to avoid contamination with feathers, scales and debris. The excreta sample from each replicate cage was dried at $85^{\circ} \mathrm{C}$ for $48 \mathrm{~h}$. The dried excreta samples were later ground to pass through a $0.5 \mathrm{~mm}$ sieve and stored in airtight containers at $-20^{\circ} \mathrm{C}$ for the analysis of AIA, gross energy (GE), calcium (Ca) and P. On
Day 25, all birds were killed by cervical dislocation (MeraZúñiga et al. 2019) and the contents of the lower half of the ileum were collected. The ileum was defined as the portion of the small intestine extending from the Meckel's diverticulum to a point $\sim 40 \mathrm{~mm}$ proximal to the ileo-caecal junction. The ileum was divided into two halves, and the digesta were collected from the lower half towards the ileo-caecal junction. The pooled ileal digesta contents from each cage were immediately frozen at $-20^{\circ} \mathrm{C}$ and then freeze-dried. Samples of the assay diets and freeze-dried ileal digesta samples were then finely ground to pass through a $0.5 \mathrm{~mm}$ sieve and stored in airtight containers at $-20^{\circ} \mathrm{C}$ for the analysis of AIA, CP, Ca, $\mathrm{P}$ and amino acid contents.

\section{Chemical analysis}

The GE contents of diet and excreta samples were determined from a $1 \mathrm{~g}$ sample using an adiabatic bomb calorimeter (IKA ${ }^{\circledR}$ - WERKE, C2000, GMBH and Co., KG, Staufen, Germany), which had been standardised with benzoic acid. Amino acid composition of the diets and ileal digesta samples was determined at the Department of Molecular Science, Australian Proteome Analysis Facility (Macquarie University, New South Wales, Australia). Amino acid profile analysis was performed as per Australian Proteome Analysis Facility standard operating procedure (AAA-001). Samples (100 mg per replicate) were first hydrolysed with $6 \mathrm{M}$ hydrochloric acid at $110^{\circ} \mathrm{C}$ for $24 \mathrm{~h}$. Under these conditions, asparagine was hydrolysed to aspartic acid and glutamine to glutamic acid; thus, the reported amount of these acids is the sum of those respective components. After hydrolysis, all amino acids were labelled using the Waters AccQTag Ultra chemistry (following supplier's recommendations) and analysed on a Waters Acquity UPLC. Cystine and tryptophan concentrations were not determined. Nitrogen

Table 2. Ingredient composition of experimental diets used in the amino acid digestibility assay (Experiment 2; g/kg as-fed basis)

SBM, soybean meal; LP, lupin; SSFLP, solid-state fermented lupin

\begin{tabular}{lcccccc}
\hline Ingredient & SBM & LP & SSFLP & LP + PHY & LP + XYL & LP + PHY + XYL \\
\hline Dextrose & 505 & 244 & 244 & 244 & 244 & 244 \\
Test ingredient & 402 & 650 & 650 & 650 & 650 & 650 \\
Canola oil & 60 & 60 & 60 & 60 & 60 & 60 \\
Limestone & 3 & 4 & 4 & 4 & 4 & 4 \\
Sodium chloride & 2 & 2 & 2 & 2 & 2 & 2 \\
Sodium bicarbonate & - & 2 & 2 & 2 & 2 & 5 \\
Vitamin and mineral premix & 5 & 5 & 5 & 5 & 5 & 3 \\
Choline chloride & 3 & 3 & 3 & 3 & 3 & 20 \\
Celite & 20 & 20 & 20 & 20 & 20 & + \\
Cellulose & - & 10 & 10 & 10 & 10 & + \\
PHY & - & - & - & + & - & + \\
XYL $^{\mathrm{C}}$ & - & - & - & - & + & + \\
\hline
\end{tabular}

${ }^{\mathrm{A}}$ Each $2 \mathrm{~kg}$ contains the following: vitamin A, 10 milli international units (MIU); vitamin D3, $2.5 \mathrm{MIU}$; vitamin E, $30 \mathrm{~g}$; vitamin K3, 2 g; vitamin B1, 1.5 g; vitamin B2, 8 g; vitamin B6, 4 g; vitamin B12, 20 mg; vitamin B5, 14 g; vitamin B9, 2 g; vitamin B3, $45 \mathrm{~g}$; vitamin H, $135 \mathrm{mg}$; cobalt, $20 \mathrm{mg}$; copper, $6 \mathrm{~g}$; iron, $50 \mathrm{~g}$; iodine, $750 \mathrm{mg}$; manganese, $75 \mathrm{~g}$; molybdenum, $1 \mathrm{~g}$; selenium, $150 \mathrm{mg}$; zinc, $60 \mathrm{~g}$.

${ }^{\mathrm{B}} \mathrm{PHY}$ : phytase added at $500 \mathrm{FTU} / \mathrm{kg}$.

${ }^{\mathrm{C}} \mathrm{XYL}$ : xylanase added at $1000 \mathrm{U} / \mathrm{kg}$. 
(N) concentration was determined on a $0.25 \mathrm{~g}$ sample with a $\mathrm{N}$ analyser (Elementar vario MACRO CHN/CHNS, Hanau, Germany). The CP content of samples was calculated by multiplying percentage $\mathrm{N}$ by a correction factor of 6.25 . The AIA contents of diets, ileal digesta and excreta samples were measured after ashing the samples and treating the ash with boiling $4 \mathrm{~mol} / \mathrm{L}$ hydrochloric acid (Mollah et al. 1983).

\section{Digestibility and apparent metabolisable energy (AME)} calculation

Apparent ileal digestibility of $\mathrm{CP}$ and amino acids was calculated using AIA as an indigestible marker. Celite was added to assay diets to increase the AIA fraction and to improve the precision of the measurement.

The AID and AME were determined by the marker method, by using the following equations, as performed by Robbins and Firman (2006) on ileal digesta:

$$
\operatorname{AID}(\%)=[1-[(\text { AIA in diet/AIA in ileal digesta })
$$$$
\times \text { (Nutrient concentration in ileal digesta/Nutrient }
$$

$$
\text { concentration in diet)]] } \times 100
$$

$\operatorname{AME}(\mathrm{MJ} / \mathrm{kg})=\mathrm{GE}$ in diet $\times[1-(\mathrm{AIA}$ in diet/AIA in excreta $)$

$$
\times(\mathrm{GE} \text { in excreta/GE in diet })]
$$

Nutrient retention $(\%)=[$ Nutrient in diet $-[$ Nutrient in excreta

$$
\times(\text { marker in diet/marker in excreta) })] \times 100,
$$

where $\mathrm{AID} \%=$ percentage $\mathrm{AID}$; AIA $=$ acid insoluble ash; $\mathrm{AME}=$ apparent metabolisable energy; $\mathrm{GE}=$ gross energy.

\section{Statistical analyses}

The data collected were analysed by one-way ANOVA using the IBM SPSS Statistics V.25 (IBM Corp., NY, USA). Differences were considered to be significant when $P<0.05$. Significant differences between means were separated using the Tukey's procedure.

\section{Results}

The analysed chemical composition of LP and SSFLP used in the present study was presented in an earlier report (Olukomaiya et al. 2020a). The LP used was analysed to contain $358 \mathrm{~g} / \mathrm{kg} \mathrm{CP}, 61 \mathrm{~g} / \mathrm{kg}$ ether extract, $36 \mathrm{~g} / \mathrm{kg}$ crude ash, 1 $\mathrm{g} / \mathrm{kg} \mathrm{Ca}, 3 \mathrm{~g} / \mathrm{kg} \mathrm{P}, 289 \mathrm{~g} / \mathrm{kg} \mathrm{NDF}$ and $208 \mathrm{~g} / \mathrm{kg} \mathrm{ADF}$. Also, SSFLP used contained $353 \mathrm{~g} / \mathrm{kg} \mathrm{CP}, 63 \mathrm{~g} / \mathrm{kg}$ ether extract, $37 \mathrm{~g} / \mathrm{kg}$ crude ash, $1 \mathrm{~g} / \mathrm{kg} \mathrm{Ca}, 4 \mathrm{~g} / \mathrm{kg} \mathrm{P}, 374 \mathrm{~g} / \mathrm{kg} \mathrm{NDF}$ and $230 \mathrm{~g} / \mathrm{kg}$ ADF. The fibre fractions were similar in the LP and SSFLP. The analysed amino acid composition of SBM, LP and SSFLP is presented in Table 3. Arginine was the most abundant essential amino acid, while glutamic acid was found to be the most abundant non-essential amino acid.

\section{Performance of broiler chickens}

There was only one mortality in total (data not shown), and birds looked healthy throughout the trial. Effect of experimental diets on performance of broiler chickens from 1 to 21 days post-hatch is presented in Table 4. From 1 to

\begin{tabular}{|c|c|c|c|}
\hline \multirow[t]{2}{*}{ Item } & \multicolumn{3}{|c|}{ Ingredient } \\
\hline & $\begin{array}{c}\text { Soybean } \\
\text { meal }\end{array}$ & Lupin & $\begin{array}{c}\text { Solid-state } \\
\text { fermented lupin }\end{array}$ \\
\hline Crude protein & 475 & 358 & 353 \\
\hline \multicolumn{4}{|c|}{ Essential amino acids ${ }^{A}$} \\
\hline Arginine & 38.1 & 33.3 & 29.5 \\
\hline Histidine & 14.1 & 8.9 & 8.0 \\
\hline Isoleucine & 25.6 & 14.0 & 13.8 \\
\hline Leucine & 42.7 & 22.8 & 22.8 \\
\hline Lysine & 31.9 & 15.9 & 11.8 \\
\hline Methionine & 6.1 & 1.9 & 1.6 \\
\hline Phenylalanine & 27.9 & 13.3 & 12.8 \\
\hline Threonine & 21.7 & 11.8 & 11.5 \\
\hline Valine & 26.4 & 13.5 & 13.3 \\
\hline \multicolumn{4}{|c|}{ Non-essential amino acids ${ }^{A}$} \\
\hline Alanine & 22.4 & 11.0 & 11.0 \\
\hline Aspartic acid & 57.2 & 33.3 & 31.8 \\
\hline Glutamic acid & 94.9 & 69.9 & 67.4 \\
\hline Glycine & 23.0 & 14.1 & 14.0 \\
\hline Proline & 27.5 & 13.5 & 13.4 \\
\hline Serine & 27.9 & 15.9 & 15.6 \\
\hline Tyrosine & 15.6 & 9.2 & 8.5 \\
\hline
\end{tabular}
7 days, dietary treatments did not have any effect $(P>0.05)$ on
Table 3. Analysed crude protein and amino acid composition of ingredients ( $\mathrm{g} / \mathrm{kg} \mathrm{DM}$ basis)

${ }^{\mathrm{A}}$ Analyses were performed in duplicate.

the performance of the broiler chickens. From 8 to 14 days, broiler chickens fed SBM and LP + PHY diets had a significantly $(P<0.05)$ higher BWG than those in other treatments. Broiler chickens fed SBM and LP + PHY diets showed a significantly $(P<0.05)$ higher FI than did those fed SSFLP, LP + XYL and LP + PHY + XYL diets, but did not differ significantly $(P>0.05)$ from those fed the LP diet. The dietary treatments did not have any effect $(P>0.05)$ on the FCR of the birds. From 15 to 21 days, broiler chickens fed SSFLP and LP diets showed lower $(P<0.05)$ BWG than birds fed the SBM diet. The SSFLP diet produced the lowest $(P<0.05)$ BWG among all treatments. The BWG in birds fed the SBM diets did not differ significantly $(P>0.05)$ from that of birds fed enzyme-supplemented LP diets. Broiler chickens fed the SBM diet had the highest $(P<0.05)$ FI, which was not significantly $(P>0.05)$ different from those fed the LP + PHY diet. Feeding the SSFLP diet resulted in the lowest $(P<0.05)$ FI compared with other treatments. The FCR was improved $(P<0.05)$ in broiler chickens fed SBM and LP-based diets, except in those fed the SSFLP diet. During the entire experimental period (1-21 days), broiler chickens fed SBM and LP + PHY diets had the highest BWG and FI, and these were significantly $(P<0.05)$ higher than those of other treatments. It was also observed that the dietary inclusion of SBM and the enzyme-supplemented LP diets significantly $(P<0.05)$ improved the FCR in the birds when compared with the SSFLP diet.

\section{AME and amino acid digestibility}

The effect of experimental diets on AID of nutrients and amino acids in broiler chickens at 25 days of age is presented in Table 5. The AME of the SBM diet was the highest $(P<0.05)$ 
Table 4. Effect of experimental diets on the performance of broiler chickens from 1 to 21 days post-hatch (Experiment 1) Values are the mean of five replicates. BWG, bodyweight gain; FI, feed intake; FCR, feed conversion ratio; SBM, soybean meal; LP, lupin; SSFLP, solid-state fermented lupin; LP + PHY, lupin + phytase; LP + XYL, lupin + xylanase; LP + PHY + XYL, lupin + phytase + xylanase; PHY, phytase added at $500 \mathrm{FTU} / \mathrm{kg}$; XYL, xylanase added at $1000 \mathrm{U} / \mathrm{kg}$; s.e.m., standard error of the mean. Means in the same column followed by different lowercase letters are significantly different (at $P=0.05$ )

\begin{tabular}{|c|c|c|c|c|c|c|c|c|c|c|c|c|}
\hline \multirow[t]{2}{*}{$\overline{\text { Diet }}$} & \multicolumn{3}{|c|}{$1-7$ days } & \multicolumn{3}{|c|}{$8-14$ days } & \multicolumn{3}{|c|}{ 15-21 days } & \multicolumn{3}{|c|}{ 1-21 days } \\
\hline & $\begin{array}{l}\text { BWG } \\
\text { (g/bird) }\end{array}$ & $\begin{array}{c}\text { FI } \\
(\mathrm{g} / \mathrm{bird})\end{array}$ & $\begin{array}{l}\text { FCR } \\
(\mathrm{g} / \mathrm{g})\end{array}$ & $\begin{array}{l}\text { BWG } \\
\text { (g/bird) }\end{array}$ & $\begin{array}{c}\text { FI } \\
\text { (g/bird) }\end{array}$ & $\begin{array}{l}\text { FCR } \\
(\mathrm{g} / \mathrm{g})\end{array}$ & $\begin{array}{l}\text { BWG } \\
\text { (g/bird) }\end{array}$ & $\begin{array}{c}\text { FI } \\
(\mathrm{g} / \mathrm{bird})\end{array}$ & $\begin{array}{l}\text { FCR } \\
(\mathrm{g} / \mathrm{g})\end{array}$ & $\begin{array}{l}\text { BWG } \\
\text { (g/bird) }\end{array}$ & $\begin{array}{c}\text { FI } \\
\text { (g/bird) }\end{array}$ & $\begin{array}{l}\text { FCR } \\
(\mathrm{g} / \mathrm{g})\end{array}$ \\
\hline SBM & 127 & 128 & 1.01 & $324 a$ & $376 a$ & 1.16 & $584 a$ & $694 a$ & $1.19 \mathrm{~b}$ & $1035 \mathrm{a}$ & $1198 \mathrm{a}$ & $1.16 \mathrm{~b}$ \\
\hline LP & 121 & 121 & 1.00 & $292 b$ & $356 a b$ & 1.22 & $534 \mathrm{~b}$ & $641 b c$ & $1.20 \mathrm{~b}$ & $947 \mathrm{~b}$ & $1118 b$ & $1.18 \mathrm{ab}$ \\
\hline SSFLP & 123 & 123 & 1.00 & $289 b$ & $350 \mathrm{~b}$ & 1.21 & $482 \mathrm{c}$ & $619 \mathrm{c}$ & $1.28 \mathrm{a}$ & $895 \mathrm{c}$ & $1092 b$ & $1.22 \mathrm{a}$ \\
\hline $\mathrm{LP}+\mathrm{PHY}$ & 128 & 124 & 0.97 & $318 \mathrm{a}$ & $372 \mathrm{a}$ & 1.17 & $577 \mathrm{ab}$ & $683 \mathrm{ab}$ & $1.18 \mathrm{~b}$ & $1022 \mathrm{a}$ & $1180 \mathrm{a}$ & $1.15 \mathrm{~b}$ \\
\hline $\mathrm{LP}+\mathrm{XYL}$ & 122 & 119 & 0.98 & $295 b$ & $343 b$ & 1.16 & $543 \mathrm{ab}$ & $649 b c$ & $1.20 \mathrm{~b}$ & $960 \mathrm{~b}$ & $1112 b$ & $1.16 \mathrm{~b}$ \\
\hline $\mathrm{LP}+\mathrm{PHY}+\mathrm{XYL}$ & 120 & 122 & 1.02 & $289 b$ & $350 \mathrm{~b}$ & 1.21 & $561 \mathrm{ab}$ & $654 \mathrm{abc}$ & $1.17 \mathrm{~b}$ & $970 \mathrm{~b}$ & $1126 \mathrm{~b}$ & $1.16 \mathrm{~b}$ \\
\hline s.e.m. & 1.05 & 1.13 & 0.01 & 3.92 & 2.90 & 0.01 & 7.52 & 5.98 & 0.01 & 10.41 & 8.56 & 0.01 \\
\hline
\end{tabular}

Table 5. Effect of experimental diets on apparent ileal digestibility (\%) of nutrients and amino acids in broiler chickens at 25 days of age (Experiment 2)

AME values relate to the diet and digestibility to ingredients. Each value represents the mean of five replicates. AME, apparent metabolisable energy; CP, crude protein; SBM, soybean meal; LP, lupin; SSFLP, solid-state fermented lupin; PHY, phytase added at $500 \mathrm{FTU} / \mathrm{kg}$; XYL, xylanase added at $1000 \mathrm{U} / \mathrm{kg}$; s.e.m., standard error of the mean. Means in the same row followed by different lowercase letters are significantly different (at $P=0.05$ )

\begin{tabular}{|c|c|c|c|c|c|c|c|}
\hline \multirow[t]{2}{*}{ Item } & \multicolumn{7}{|c|}{ Diet } \\
\hline & SBM & LP & SSFLP & $\mathrm{LP}+\mathrm{PHY}$ & $\mathrm{LP}+\mathrm{XYL}$ & $\mathrm{LP}+\mathrm{PHY}+\mathrm{XYL}$ & s.e.m. \\
\hline $\operatorname{AME}(\mathrm{MJ} / \mathrm{kg})$ & $15.0 \mathrm{a}$ & $11.0 \mathrm{~b}$ & $12.0 \mathrm{~b}$ & $11.0 \mathrm{~b}$ & $11.0 \mathrm{~b}$ & $10.0 \mathrm{~b}$ & 0.35 \\
\hline $\mathrm{CP}$ & 88.0 & 85.0 & 81.0 & 82.0 & 86.0 & 89.0 & 1.12 \\
\hline \multicolumn{8}{|c|}{ Essential amino acids } \\
\hline Arginine & $92.8 \mathrm{bc}$ & $94.7 \mathrm{ab}$ & $92.3 \mathrm{c}$ & 93.1abc & $93.1 \mathrm{abc}$ & $95.1 \mathrm{a}$ & 0.27 \\
\hline Histidine & 89.1 & 87.5 & 82.4 & 85.0 & 84.5 & 88.0 & 0.77 \\
\hline Isoleucine & 88.5 & 86.1 & 86.9 & 85.1 & 84.3 & 88.3 & 0.49 \\
\hline Leucine & 88.8 & 87.4 & 88.6 & 87.0 & 86.0 & 89.6 & 0.42 \\
\hline Lysine & $89.0 \mathrm{a}$ & $85.5 \mathrm{a}$ & $80.3 b$ & $87.2 \mathrm{a}$ & $86.4 \mathrm{a}$ & $88.7 \mathrm{a}$ & 0.66 \\
\hline Methionine & $92.4 \mathrm{a}$ & $85.3 \mathrm{~b}$ & $77.8 \mathrm{c}$ & $86.0 \mathrm{~b}$ & $79.3 \mathrm{c}$ & $89.2 \mathrm{ab}$ & 1.07 \\
\hline Phenylalanine & 89.8 & 87.9 & 88.9 & 87.3 & 86.5 & 89.7 & 0.41 \\
\hline Threonine & 80.4 & 79.1 & 80.4 & 77.0 & 78.5 & 83.0 & 0.69 \\
\hline Valine & 86.7 & 83.4 & 85.9 & 82.6 & 82.9 & 86.6 & 0.56 \\
\hline Mean & 88.6 & 86.3 & 84.8 & 85.6 & 84.6 & 88.7 & 0.52 \\
\hline \multicolumn{8}{|c|}{ Non-essential amino acids } \\
\hline Alanine & 85.0 & 79.7 & 85.0 & 82.4 & 81.2 & 84.7 & 0.64 \\
\hline Aspartic acid & $82.6 b$ & $85.1 \mathrm{ab}$ & $81.5 b$ & $85.2 \mathrm{ab}$ & $85.4 \mathrm{ab}$ & $88.3 \mathrm{a}$ & 0.60 \\
\hline Glutamic acid & $88.7 \mathrm{~b}$ & $90.2 \mathrm{ab}$ & $90.4 \mathrm{ab}$ & $90.9 \mathrm{ab}$ & $90.0 \mathrm{ab}$ & $92.3 \mathrm{a}$ & 0.35 \\
\hline Glycine & 82.3 & 82.7 & 81.9 & 83.5 & 82.3 & 86.0 & 0.55 \\
\hline Proline & 85.5 & 81.7 & 84.1 & 81.7 & 81.3 & 85.3 & 0.61 \\
\hline Serine & 85.6 & 83.2 & 82.3 & 81.9 & 82.1 & 86.1 & 0.56 \\
\hline Tyrosine & 90.0 & 89.8 & 88.0 & 87.9 & 87.1 & 90.9 & 0.41 \\
\hline Mean & 85.7 & 84.6 & 84.7 & 84.8 & 84.2 & 87.7 & 0.36 \\
\hline
\end{tabular}

among all treatments, while the LP-based diets showed similar $(P>0.05)$ AME values. There was no significant $(P>0.05)$ difference in AID of CP among the experimental diets. The AID of amino acids was similar across the dietary treatments except for arginine, lysine, methionine, aspartic acid and glutamic acid. The LP + PHY + XYL diet was characterised by the highest $(P<0.05)$ AID for arginine, which was similar to that of the LP diet, while the lowest value was found in SSFLP diets. Compared with other treatments, SSFLP diet was observed to have the lowest $(P<0.05)$ AID for lysine. The AID of methionine in the SBM diet was highest $(P<0.05)$ among the treatments but statistically similar $(P>0.05)$ to that of the LP + PHY + XYL diet. The SSFLP and LP + XYL diets recorded the lowest $(P<0.05)$ AID for methionine. The AID for aspartic acid in $\mathrm{LP}+\mathrm{PHY}+\mathrm{XYL}$ diet was observed to be higher $(P<0.05)$ 
Table 6. Effect of experimental diets on apparent ileal digestibility and retention (\%) of calcium and phosphorus in broiler chickens at 25 days of age (Experiment 2)

Values are the mean of five replicates. SBM, soybean meal; LP, lupin; SSFLP, solid-state fermented lupin; LP + PHY, lupin + phytase; LP + XYL, lupin + xylanase; $\mathrm{LP}+\mathrm{PHY}+\mathrm{XYL}$, lupin + phytase + xylanase; $\mathrm{PHY}$, phytase added at $500 \mathrm{FTU} / \mathrm{kg}$; XYL, xylanase added at $1000 \mathrm{U} / \mathrm{kg}$; s.e.m., standard error of the mean. Means in the same row followed by different lowercase letters are significantly different (at $P=0.05$ )

\begin{tabular}{lcccc}
\hline Diet & \multicolumn{2}{c}{ Ileal digestibility (\%) } & \multicolumn{2}{c}{ Retention (\%) } \\
& Calcium & Phosphorus & Calcium & Phosphorus \\
\hline SBM & $57 \mathrm{~b}$ & $64 \mathrm{c}$ & $48 \mathrm{~b}$ & $53 \mathrm{ab}$ \\
LP & $72 \mathrm{a}$ & $69 \mathrm{bc}$ & $66 \mathrm{a}$ & $43 \mathrm{abc}$ \\
SSFLP & $77 \mathrm{a}$ & $75 \mathrm{ab}$ & $72 \mathrm{a}$ & $54 \mathrm{a}$ \\
LP + PHY & $73 \mathrm{a}$ & $73 \mathrm{ab}$ & $62 \mathrm{ab}$ & $31 \mathrm{c}$ \\
LP + XYL & $71 \mathrm{a}$ & $63 \mathrm{c}$ & $67 \mathrm{a}$ & $31 \mathrm{c}$ \\
LP+ PHY+ XYL & $67 \mathrm{ab}$ & $79 \mathrm{a}$ & $64 \mathrm{ab}$ & $36 \mathrm{bc}$ \\
s.e.m. & 1.53 & 1.23 & 1.91 & 2.28 \\
\hline
\end{tabular}

than that of SBM and SSFLP diets, while that found in LP, LP + PHY and LP + XYL diets was intermediate. The AID of glutamic acid in the LP + PHY + XYL diet was higher $(P<0.05)$ than that of the SBM diet, but did not differ $(P>0.05)$ from that of the other LP-based diets. The effect of experimental diets on AID and retention of $\mathrm{Ca}$ and $\mathrm{P}$ in broiler chickens at 25 days of age is presented in Table 6 . The AID of Ca in LP, SSFLP, LP + PHY and LP + XYL diets was higher $(P<0.05)$ than that in the SBM diet, but not different $(P>0.05)$ from that of the LP + PHY + XYL diet. The AID of $\mathrm{P}$ in the LP $+\mathrm{PHY}+\mathrm{XYL}$ diet was higher $(P<0.05)$ than that in SBM and LP+XYL diets, but similar $(P>0.05)$ to that of SSFLP and LP + PHY diets. Ca retention in LP, SSFLP and LP + XYL diets was higher $(P<0.05)$ than that in the SBM diet, but did not differ $(P>0.05)$ from that in LP + PHY and LP + PHY + XYL diets. P retention in SSFLP diet was the highest $(P<0.05)$ among the treatments, but statistically similar $(P>0.05)$ to that of the SBM diet.

\section{Discussion}

\section{Performance of broiler chickens}

The effect of inclusion of LP at $250 \mathrm{~g} / \mathrm{kg}$ in broiler diets has been previously reported (Roth-Maier and Paulicks 2003; Smulikowska et al. 2014; Mera-Zúñiga et al. 2019). In the report of Steenfeldt et al. (2003), dietary inclusion of LP at 200 $\mathrm{g} / \mathrm{kg}$ significantly reduced BWG and FCR in broilers from 7 to 21 days of age. In the present study, from 8 to 14 days, broiler chickens fed SBM and LP + PHY diets had higher BWG and FI than did those in the other treatments. A similar trend was also observed during the entire experimental period (1-21 days), with birds fed the SBM diet and the $250 \mathrm{~g} / \mathrm{kg}$ LP diet supplemented with PHY showing the highest BWG and FI compared with those in the other treatments. In line with the present finding, the positive influence of PHY supplementation on broiler performance has been well established (Wu et al. 2004; Cowieson et al. 2006; Selle et al. 2012; Babatunde et al. 2019; Ciurescu et al. 2020; Attia et al. 2020). However, Woyengo et al. (2008) did not observe any improvement in performance as a result of supplementing broiler diet with PHY. This improvement in broiler response may be attributed to the hydrolysis of phytate complexes, leading to an increased release of proteins and amino acids for digestion and absorption (Selle et al. 2000; Onyango et al. 2004).

Unlike the trend observed with the LP + PHY diet, the LP + XYL diet and the LP + PHY + XYL diet did not enhance the performance of broilers from 1 to 21 days. Conflicting evidence exists on the impact of XYL and the combination of PHY and XYL on broiler performance. For instance, $\mathrm{Wu}$ et al. (2004) reported improvement by XYL on the performance in broiler chickens fed wheat-based diets, whereas Pekel et al. (2017) reported that XYL did not improve nutrient utilisation and performance of broiler chickens fed camelina meal-based diets. Furthermore, Woyengo et al. (2008) did not observe any improvement in performance as a result of supplementing broiler diet with PHY and XYL, while Selle et al. (2003) reported that the inclusion of PHY and XYL improved BWG and feed efficiency of broilers (7-28 days post-hatch). With regards to our results, the response to feed enzymes is dependent on many factors such as diet composition as well as the source and level of enzyme addition (Bryden and Li 2010).

To the best of our knowledge, this is the first study to investigate the nutritional value of SSFLP in broiler chickens. From 15 to 21 days and from 1 to 21 days, dietary inclusion of SSFLP did not result in improved broiler performance, as expected. Similarly, Siriwan et al. (2005a, 2005b) reported that fermented common beans included at $5-20 \%$ in poultry diet reduced FI, BWG and feed efficiency. In contrast to the present findings, Chiang et al. (2010) and Xu et al. (2012) reported a beneficial effect of feeding fermented rapeseed meal on broiler performance. The reduced performance may partly be due to the fibre content of the SSFLP diet, as was previously reported by Olukomaiya et al. (2020a). The SSFLP used in the present study had numerically higher NDF and ADF contents, although they were not significantly higher than those of the LP. The fibre content in SSFLP diet may be responsible for the reduced performance, resulting in poor BWG, FI and FCR. High fibre content adversely affects broilers at an early age, causing reduced performance (Khajali and Slominski 2012; Gopinger et al. 2014). Under SSF conditions, microbial activities alter the physicochemical characteristics of substrates, thereby changing many features of the resultant product (Ajila et al. 2012; Olukomaiya et al. 2019c). It was also observed that the dietary inclusion of SBM and enzyme-supplemented LP diets enhanced the FCR in the birds when compared with the SSFLP diet, from 1 to 21 days. The improvement observed in the FCR from 1 to 21 days may be due to a marginal increase in the BWG of the broiler chickens relative to FI.

Overall, relative to feeding SBM and LP diets, the enzymesupplemented diets were found to induce improved performance compared with the SSFLP diets in the birds from 1 to 21 days. The reason for this observation is not clear and, thus, more studies are still needed to better understand the nutritional value of SSFLP for broiler performance. 


\section{AME and amino acid digestibility}

The amino acid contents and AID values determined for SBM and LP diets in the present study were similar to those reported previously (Bryden et al. 2009; Nalle et al. 2011). The beneficial role of enzyme supplementation in improving amino acid digestibility in broilers has been well demonstrated (Selle et al. 2003; Bryden and Li 2004; Selle et al. 2009).

In the present study, the most pronounced improvements in AID of amino acids were associated with the combined supplementation of PHY and XYL in the LP diet. The positive impact confirmed the synergistic impact of PHY and XYL on the AID of arginine, aspartic acid and glutamic acid. This finding is in agreement with the report of Selle et al. (2003) who noted similar synergistic responses for most of the amino acids subsequent to the addition of PHY and XYL to wheat-based diets. It is possible that the combined supplementation of PHY and XYL to the LP-based diet may have a supportive manner of action in improving the AID of amino acids. The improvement in AID of amino acids by both PHY and XYL may also be due to the decrease of endogenous amino acid flows (Selle et al. 2009). Low AID of methionine was observed in the LP + XYL diet compared with the SBM or LP diet, although this reduction was similar to that of the SSFLP diet. Selle et al. (2003) also reported that XYL had no effect on the AID of amino acids in broilers fed wheat-based diets. This was an unforeseen result as the ability of XYL to enhance the AID of amino acids has been previously demonstrated (Hew et al. 1998). Methionine has a minimal possibility for improvement with PHY and XYL supplementation, because basal digestibility at the terminal ileum is naturally greater than $90 \%$ in a corn-SBM diet (Rutherfurd et al. 2004; Gehring et al. 2013).

In general, the enzyme-supplemented LP diets had significant effects on AID of amino acids compared with the SSFLP diet. Ahmed et al. (2014) reported that SSF enhanced AID of amino acids in canola meal. Zaworska et al. (2017) also found that fermentation had a positive impact on the AID of amino acids in LP-based diets. However, these reports do not agree with the results of the present study. With regards to the present study, it is possible that processing conditions before incorporation into the diet may have accounted for the poor AID of amino acids observed in the SSFLP diet. Processing condition is an important factor that has been found to modify amino acid digestibility (Bryden and $\mathrm{Li}$ 2004).

It is noteworthy that it has been shown that excess $\mathrm{Ca}$ and $\mathrm{P}$ absorbed from the intestine can be excreted from urine into excreta (Li et al. 2017), which may be responsible for nutrient retention values being lower than nutrient digestibility in the present study. The positive effects of PHY and XYL on $\mathrm{Ca}$ digestibility have been reported by many authors (Ravindran et al. 2008; Khoramabadi et al. 2014; Hosseini and Afshar 2017; Fernandes et al. 2019). In the present study, birds offered SSFLP and enzyme-supplemented LP diets generated an improved response in the AID of $\mathrm{Ca}$. Also, AID of $\mathrm{P}$ was observed to improve in birds fed the LP + $\mathrm{PHY}+\mathrm{XYL}$ diet relative to those fed the SBM or LP diets.
Likewise, the improvement in Ca retention noted for LP, SSFLP and LP + XYL diets and P retention in SSFLP diet is of pivotal importance. In line with the present findings, Moss et al. (2018) reported that the combination of PHY and XYL in birds offered canola meal-based diets increased the ileal digestibility of $\mathrm{Ca}$ and $\mathrm{P}$. The synergistic action of PHY and XYL can be beneficial through improved access to cell contents in the intestinal environment (Adeola and Cowieson 2011).

Ramesh and Chandrasekaran (2011) demonstrated that pure enzyme supplementation increased retention of $\mathrm{Ca}$ and $\mathrm{P}$ in birds. $\mathrm{Ca}$ is poorly digested in broiler diets, as Amerah et al. (2014) found that AID of $\mathrm{Ca}$ ranged from $54 \%$ to $61.8 \%$ in unsupplemented corn-SBM diets, which aligns with the AID of $\mathrm{Ca}$ in the SBM diet in the present study, which was analysed to be $57 \%$. The increase in $\mathrm{Ca}$ and $\mathrm{P}$ digestibilities and retention may be explained by a clear and large breakdown of mineral-phytate complexes or the release of $\mathrm{Ca}$ and $\mathrm{P}$ from soluble fibre-bound $\mathrm{Ca}$ and $\mathrm{P}$ (Pekel et al. 2017). $\mathrm{PHY}$ catalyses the dephosphorisation reaction of phytic acid in inorganic phosphate and smaller esters that have low chelate capacity and make nutrients unavailable (Lei and Porres 2003).

In our study, reduced $\mathrm{P}$ digestibility in the LP + XYL diet and $\mathrm{P}$ retention in the $\mathrm{LP}+\mathrm{PHY}$ and $\mathrm{LP}+\mathrm{XYL}$ diets were observed. Similarly, XYL supplementation did not have an effect on ileal nutrient digestibility (Pekel et al. 2017). It is not clear which factors triggered the difference in response to $\mathrm{PHY}$ or XYL supplementation on ileal P digestibility and retention in the current study. With regards to the SSFLP diet, Chiang et al. (2010) and Mandey et al. (2015) also reported that $\mathrm{Ca}$ digestibility and retention were increased in fermented feeds compared with the unfermented control. The improvement in $\mathrm{Ca}$ and $\mathrm{P}$ digestibility and retention in SSFLP diet may be attributed to the chelating effect of organic acids from SSF on Ca (Centeno et al. 2007). During fermentation, microbial enzymes can hydrolyse the phytate complex (Ahmad et al. 2000; Sugiharto and Ranjitkar 2019), with increased phytate solubility and susceptibility to hydrolysis (Centeno et al. 2007; Esmaeilipour et al. 2011), thereby increasing the retention and utilisation of $\mathrm{Ca}$ and $\mathrm{P}$.

\section{Conclusions}

In conclusion, supplementing LP diet with PHY enhanced the performance of broiler chickens, as indicated by the BWG and FI of these birds, which were significantly higher than those of the birds fed on other LP-based diets and comparable to those birds fed on the SBM diet, from 1 to 21 days. Although the SSFLP diet did not improve broiler performance, it was effective in increasing $\mathrm{P}$ retention in broiler chickens. The inclusion of LP + PHY + XYL in the diet improved the AID of amino acids. Feeding SSFLP and enzyme-supplemented LP diets enhanced $\mathrm{Ca}$ and $\mathrm{P}$ digestibility as well as $\mathrm{Ca}$ retention. SSFLP is a promising feed ingredient and can have a potential application in feed formulation. However, further studies are still needed to be able to clearly understand its practical application at a high inclusion level on performance and ileal amino acid digestibility in broiler chickens. The 
development of cocktail inoculants to target all ANFs in LPs will definitely open a new window for the poultry feed industry.

\section{Conflicts of interest}

The authors declare no conflicts of interest.

\section{Acknowledgements}

The scholarship support through the Research Training Program Scholarship provided to Oladapo O. Olukomaiya during his PhD study at the University of Queensland and technical support from the Queensland Department of Agriculture and Fisheries are gratefully appreciated. This research did not receive any specific funding.

\section{References}

Adeola O, Cowieson AJ (2011) Board-invited review: opportunities and challenges in using exogenous enzymes to improve nonruminant animal production. Journal of Animal Science 89, 3189-3218. doi:10.2527/jas.2010-3715

Ahmad T, Rasool S, Sarwar M, Haq AU, Hasan ZU (2000) Effect of microbial phytase produced from a fungus Aspergillus niger on bioavailability of phosphorus and calcium in broiler chickens. Animal Feed Science and Technology 83, 103-114. doi:10.1016/S0377-8401 (99)00122-4

Ahmed A, Zulkifli I, Farjam AS, Abdullah N, Liang JB, Awad EA (2014) Effect of solid state fermentation on nutrient content and ileal amino acids digestibility of canola meal in broiler chickens. Italian Journal of Animal Science 13, 3293. doi:10.4081/ijas.2014.3293

Ajila CM, Brar SK, Verma M, Tyagi RD, Godbout S, Valéro JR (2012) Biol.processing of agro-byproducts to animal feed. Critical Reviews in Biotechnology 32, 382-400. doi:10.3109/07388551.2012.659172

Al-Harthi MA, Attia YA, El-Shafey AS, Elgandy MF (2020) Impact of phytase on improving the utilisation of pelleted broiler diets containing olive by-products. Italian Journal of Animal Science 19, 310-318. doi:10.1080/1828051X.2020.1740896

Amerah AM, Plumstead PW, Barnard LP, Kumar A (2014) Effect of calcium level and phytase addition on ileal phytate degradation and amino acid digestibility of broilers fed corn-based diets. Poultry Science 93, 906-915. doi:10.3382/ps.2013-03465

AOAC (2000) 'Official Methods of Analysis.' 17th edn. (Association of Official Analytical Chemists: Gaithersburg, MD, USA)

Attia YA, Bovera F, Iannaccone F, Al-Harthi MA, Alaqil AA, Zeweil HS, Mansour AE (2020) Microbial and fungal phytases can affect growth performance, nutrient digestibility and blood profile of broilers fed different levels of non-phytic phosphorous. Animals 10, 580. doi:10.3390/ani10040580

Babatunde OO, Cowieson AJ, Wilson JW, Adeola O (2019) The impact of age and feeding length on phytase efficacy during the starter phase of broiler chickens. Poultry Science 98, 6742-6750. doi:10.3382/ps/pez390

Bryden WL, Li X (2004) Utilisation of digestible amino acids by broilers. Report publication no. 04/030. Rural Industries Research and Development Corporation (RIRDC), Barton, ACT, Australia.

Bryden WL, Li X (2010) Amino acid digestibility and poultry feed formulation: expression, limitations and application. Revista Brasileira de Zootecnia 39, 279-287. doi:10.1590/S1516-3598201000 1300031

Bryden WL, Li X, Ravindran G, Hew LI, Ravindran V (2009) Ileal digestible amino acid values in feedstuffs for poultry. Report publication no. 09/ 071. Rural Industries Research and Development Corporation (RIRDC), Canberra, ACT, Australia.

Centeno C, Arija I, Viveros A, Brenes A (2007) Effects of citric acid and microbial phytase on amino acid digestibility in broiler chickens.
British Poultry Science 48, 469-479. doi:10.1080/00071660701 455276

Chaves NRB, Nascimento KM, Kiefer C, Rosa MS, Feitas HB, Paiva LL, Silva TR, Silva LA, Macie VA, Leal CR, Souza AI (2020) Phytase and xylanase in diets with nutritional adjustments and their effects on serum biochemistry, morphometry and intestinal health of broilers. Anais da Academia Brasileira de Ciências 92, e20190278. doi:10.1590/0001-3765202020190278

Chiang G, Lu WQ, Piao XS, Hu JK, Gong LM, Thacker PA (2010) Effects of feeding solid-state fermented rapeseed meal on performance, nutrient digestibility, intestinal ecology and intestinal morphology of broiler chickens. Asian-Australasian Journal of Animal Sciences 23, 263-271. doi:10.5713/ajas.2010.90145

Ciurescu G, Vasilachi A, Grosu H (2020) Efficacy of microbial phytase on growth performance, carcass traits, bone mineralization, and blood biochemistry parameters in broiler turkeys fed raw chickpea (Cicer arietinum L., cv. Burnas) diets. Journal of Applied Poultry Research 29, 171-184. doi:10.1016/j.japr.2019.10.004

Cowieson AJ, Acamovic T, Bedford MR (2006) Supplementation of corn-soy-based diets with an Eschericia coli-derived phytase: effects on broiler chick performance and the digestibility of amino acids and metabolizability of minerals and energy. Poultry Science $\mathbf{8 5}$, 1389-1397. doi:10.1093/ps/85.8.1389

Esmaeilipour O, Shivazad M, Moravej H, Aminzadeh S, Rezaian M, Van Krimpen MM (2011) Effects of xylanase and citric acid on the performance, nutrient retention, and characteristics of gastrointestinal tract of broilers fed low-phosphorus wheat-based diets. Poultry Science 90, 1975-1982. doi:10.3382/ps.2010-01264

Fernandes JIM, Horn D, Ronconi EJ, Buzim R, Lima FK, Pazdiora DA (2019) Effects of phytase superdosing on digestibility and bone integrity of broilers. Journal of Applied Poultry Research 28, 390-398. doi:10.3382/japr/pfz001

Gehring CK, Bedford MR, Dozier WA III (2013) Extra-phosphoric effects of phytase with and without xylanase in corn-soybean meal-based diets fed to broilers. Poultry Science 92, 979-991. doi:10.3382/ ps.2012-02769

Ghayour-Najafabadi P, Khosravinia H, Gheisari A, Azarfar A, Khanahmadi M (2018) Productive performance, nutrient digestibility and intestinal morphometry in broiler chickens fed corn or wheat-based diets supplemented with bacterial- or fungal-originated xylanase. Italian Journal of Animal Science 17, 165-174. doi:10.1080/1828051X. 2017.1328990

Gopinger E, Xavier EG, Elias MC, Catalan AAS, Castro MLS, Nunes AP, Roll VFB (2014) The effect of different dietary levels of canola meal on growth performance, nutrient digestibility, and gut morphology of broiler chickens. Poultry Science 93, 1130-1136. doi:10.3382/ ps.2013-03426

Hew LI, Ravindran V, Mollah Y, Bryden WL (1998) Influence of exogenous xylanase supplementation on apparent metabolisable energy and amino acid digestibility in wheat for broiler chickens. Animal Feed Science and Technology 75, 83-92. doi:10.1016/ S0377-8401(98)00206-5

Hosseini SM, Afshar M (2017) Effects of feed form and xylanase supplementation on performance and ileal nutrients digestibility of heat-stressed broilers fed wheat-soybean diet. Journal of Applied Animal Research 45, 550-556. doi:10.1080/09712119.2016.1224765

Jezierny D, Mosenthin R, Bauer E (2010) The use of grain legumes as a protein source in pig nutrition: a review. Animal Feed Science and Technology 157, 111-128. doi:10.1016/j.anifeedsci.2010.03.001

Karkalas J (1985) An improved enzymic method for the determination of native and modified starch. Journal of the Science of Food and Agriculture 36, 1019-1027. doi:10.1002/jsfa.2740361018

Kasprowicz-Potocka M, Zaworska A, Frankiewics A, Nowak W, Gulewicz P, Zduńczyk Z, Juśkiewicz J (2015) The nutritional value and 
physiological properties of diets with raw and Candida utilis-fermented lupin seeds in rats. Food Technology and Biotechnology 53, 286-297. doi:10.17113/ftb.53.03.15.3979

Khajali F, Slominski BA (2012) Factors that affect the nutritive value of canola meal for poultry. Poultry Science 91, 2564-2575. doi:10.3382/ ps.2012-02332

Khoramabadi V, Akbari MR, Khajali F, Noorani H, Rahmatnejad E (2014) Influence of xylanase and vitamin $\mathrm{A}$ in wheat-based diet on performance, nutrients digestibility, small intestinal morphology and digesta viscosity in broiler chickens. Acta Scientiarum. Animal Sciences 36, 379-384. doi:10.4025/actascianimsci.v36i4.23910

Kim JC, Mullan BP, Nicholls RR, Pluske JR (2011) Effect of Australian sweet lupin (Lupinus angustifolius L.) inclusion levels and enzyme supplementation on the performance, carcass composition and meat quality of grower/finisher pigs. Animal Production Science 51, 37-43. doi:10.1071/AN10087

Kong C, Adeola O (2011) Protein utilization and amino acid digestibility of canola meal in response to phytase in broiler chickens. Poultry Science 90, 1508-1515. doi:10.3382/ps.2011-01363

Lee MR, Parkinson S, Fleming HR, Theobald VJ, Leemans DK, Burgess T (2016) The potential of blue lupins as a protein source in the diets of laying hens. Veterinary and Animal Science 1-2, 29-35. doi:10.1016/j. vas.2016.11.004

Lei XG, Porres JM (2003) Phytase enzymology, applications, and biotechnology. Biotechnology Letters 25, 1787-1794. doi:10.1023/ A: 1026224101580

Li X, Zhang D, Bryden WL (2017) Calcium and phosphorus metabolism and nutrition of poultry: are current diets formulated in excess? Animal Production Science 57, 2304-2310. doi:10.1071/AN17389

Mandey JS, Leke JR, Rahasia CA (2015) Calcium and phosphorus excretion and retention in diets of laying hens fed soybean waste fermented by Trichoderma viride. Livestock Research for Rural Development 27, 11

Mera-Zúñiga F, Pro-Martínez A, Zamora-Natera JF, Sosa-Montes E, Guerrero-Rodríguez JD, Mendoza-Pedroza SI, Cuca-García JM, López-Romero RM, Chan-Díaz D, Becerril-Pérez CM, Vargas-Galicia AJ, Bautista-Ortega J (2019) Soybean meal substitution by dehulled lupine (Lupinus angustifolius) with enzymes in broiler diets. AsianAustralasian Journal of Animal Sciences 32, 564-573.

Mollah Y, Bryden WL, Wallis IR, Balnave D, Annison EF (1983) Studies on low metabolisable energy wheats for poultry using conventional and rapid assay procedures and the effects of processing. British Poultry Science 24, 81-89. doi:10.1080/00071668308416716

Moss AF, Chrystal PV, Dersjant-Li Y, Selle PH, Liu SY (2018) Responses in digestibilities of macro-minerals, trace minerals and amino acids generated by exogenous phytase and xylanase in canola meal diets offered to broiler chickens. Animal Feed Science and Technology 240, 22-30. doi:10.1016/j.anifeedsci.2018.03.011

Nalle CL, Ravindran V, Ravindran G (2011) Nutritional value of narrowleafed lupin (Lupinus angustifolius) for broilers. British Poultry Science 52, 775-781. doi:10.1080/00071668.2011.639343

National Health and Medical Research Council (1990) 'Australian Code of Practice for the Care and Use of Animals for Scientific Purposes.' (National Health and Medical Research Council, Commonwealth Scientific and Industrial, Research Organization, Australian Agricultural Council, Australian Government Public Service: Canberra, ACT, Australia)

Olkowski AA, Olkowski BI, Amarowicz R, Classen HL (2001) Adverse effects of dietary lupine in broiler chickens. Poultry Science 80, 621-625. doi:10.1093/ps/80.5.621

Olukomaiya OO, Fernando WC, Mereddy R, Zhang D, Li X, Sultanbawa Y (2019a) Phytic acid reduction in canola and camelina meals by fungal fermentation for potential broiler feeding. In 'Proceedings of the Australian Poultry Science Symposium. 30th Annual Australian
Poultry Science Symposium', Sydney, NSW, Australia, 17-20 February 2019. (Ed. J Roberts) pp. 203-203.

Olukomaiya OO, Fernando WC, Mereddy R, Li X, Sultanbawa Y (2019b) Nutritional analysis of solid-state fermented canola meal (an improved protein source for broilers). In 'Proceedings of the 22nd European Symposium on Poultry Nutrition', Gdansk, Poland, 10-13 June 2019. pp. 167-167.

Olukomaiya OO, Fernando WC, Mereddy R, Li X, Sultanbawa Y (2019c) Solid-state fermented plant protein sources in the diets of broiler chickens: a review. Animal Nutrition 5, 319-330. doi:10.1016/j. aninu.2019.05.005

Olukomaiya OO, Fernando WC, Mereddy R, Li X, Sultanbawa Y (2019d) Nutritional composition of solid-state fermented camelina meal (an enriched protein source for broiler chickens). Proceedings 36, 106. doi:10.3390/proceedings2019036106

Olukomaiya OO, Adiamo OQ, Fernando WC, Mereddy R, Li X, Sultanbawa Y (2020a) Effect of solid-state fermentation on proximate composition, anti-nutritional factor, microbiological and functional properties of lupin flour. Food Chemistry 315, 126238. doi:10.1016/j.foodchem.2020.126238

Olukomaiya OO, Fernando WC, Mereddy R, Li X, Sultanbawa Y (2020b) Solid-state fermentation of canola meal with Aspergillus sojae, Aspergillus ficuum and their co-cultures: effects on physicochemical, microbiological and functional properties. Lebensmittel-Wissenschaft + Technologie 127, 109362. doi:10.1016/j.1wt.2020.109362

Olukomaiya OO, Fernando WC, Mereddy R, Li X, Sultanbawa Y (2020c) Physicochemical, microbiological and functional properties of camelina meal fermented in solid-state using food grade Aspergillus fungi. Fermentation 6, 44. doi:10.3390/fermentation6020044

Olukomaiya OO, Pan L, Zhang D, Mereddy R, Sultanbawa Y, Li X (2021) Performance and ileal amino acid digestibility in growing male broilers fed diets containing solid-state fermented and enzymesupplemented canola meals. Animal Feed Science and Technology 275, 114876. doi:10.1016/j.anifeedsci.2021.114876

Onyango EM, Bedford MR, Adeola O (2004) The yeast production system in which Escherichia coli phytase is expressed may affect growth performance, bone ash, and nutrient use in broiler chicks. Poultry Science 83, 421-427. doi:10.1093/ps/83.3.421

Pekel AY, Horn NL, Adeola O (2017) The efficacy of dietary xylanase and phytase in broiler chickens fed expeller-extracted camelina meal. Poultry Science 96, 98-107. doi:10.3382/ps/pew183

Ramesh J, Chandrasekaran D (2011) Effect of exogenous enzyme supplementation on performance of cockerels. Indian Journal of Veterinary and Animal Sciences Research 7, 29-34.

Ravindran V, Cowieson AJ, Selle PH (2008) Influence of dietary electrolyte balance and microbial phytase on growth performance, nutrient utilization, and excreta quality of broiler chickens. Poultry Science 87, 677-688. doi:10.3382/ps.2007-00247

Robbins DH, Firman JD (2006) Evaluation of the metabolizable energy of poultry by-product meal for chickens and turkeys by various methods. International Journal of Poultry Science 5, 753-758. doi:10.3923/ ijps.2006.753.758

Roth-Maier DA, Paulicks BR (2003) Feeding and nutritional value of sweet blue and yellow lupin seed (Lupinus angustifolius L., Lupinus luteus L.) for broiler chicks. Archiv für Geflügelkunde 67, 175-178.

Rutherfurd SM, Chung TK, Morel PC, Moughan PJ (2004) Effect of microbial phytase on ileal digestibility of phytate phosphorus, total phosphorus, and amino acids in a low-phosphorus diet for broilers. Poultry Science 83, 61-68. doi:10.1093/ps/83.1.61

Selle PH, Ravindran V, Caldwell A, Bryden WL (2000) Phytate and phytase: consequences for protein utilisation. Nutrition Research Reviews 13, 255-278. doi:10.1079/095442200108729098

Selle PH, Ravindran V, Ravindran G, Pittolo PH, Bryden WL (2003) Influence of phytase and xylanase supplementation on growth 
performance and nutrient utilisation of broilers offered wheat-based diets. Asian-Australasian Journal of Animal Sciences 16, 394-402. doi:10.5713/ajas.2003.394

Selle PH, Ravindran V, Partridge GG (2009) Beneficial effects of xylanase and/or phytase inclusions on ileal amino acid digestibility, energy utilisation, mineral retention and growth performance in wheat-based broiler diets. Animal Feed Science and Technology 153, 303-313. doi:10.1016/j.anifeedsci.2009.06.011

Selle PH, Cowieson AJ, Cowieson NP, Ravindran V (2012) Protein-phytate interactions in pig and poultry nutrition: a reappraisal. Nutrition Research Reviews 25, 1-17. doi:10.1017/ S0954422411000151

Shi C, He J, Yu J, Yu B, Huang Z, Mao X, Zheng P, Chen D (2015) Solid state fermentation of rapeseed cake with Aspergillus niger for degrading glucosinolates and upgrading nutritional value. Journal of Animal Science and Biotechnology 6, 13. doi:10.1186/s40104015-0015-2

Siriwan P, Pimsan S, Nakkitset S (2005a) The use of fermented red kidney bean as a feed supplement in broilers' diet. In 'Proceedings of the 43rd Kasetsart University Annual Conference', Bangkok, Thailand, 1-4 February 2005. (Ed P Vichulta) pp. 220-228. (Kasetsart University Press: Bangkok)

Siriwan P, Pimsan S, Nakkitset S (2005b) The use of ground red kidney bean as a feed supplement in broilers' diet. In 'Proceedings of the 43rd Kasetsart University Annual Conference', Bangkok, Thailand, 1-4 February 2005. (Ed P Vichulta) pp. 229-236. (Kasetsart University Press: Bangkok)

Smulikowska S, Konieczka P, Czerwinski J, Mieczkowska A, Jankowiak J (2014) Feeding broiler chickens with practical diets containing lupin seeds (L. angustifolius or L. luteus): effects of incorporation level and mannanase supplementation on growth performance, digesta viscosity, microbial fermentation and gut morphology. Journal of Animal and Feed Sciences 23, 64-72. doi:10.22358/jafs/65718/2014

Soccol CR, da Costa ESF, Letti LAJ, Karp SG, Woiciechowski AL, de Souza Vandenberghe LP (2017) Recent developments and innovations in solid state fermentation. Biotechnology Research and Innovation 1, 52-71. doi:10.1016/j.biori.2017.01.002

Steenfeldt S, González E, Knudsen KB (2003) Effects of inclusion with blue lupins (Lupinus angustifolius) in broiler diets and enzyme supplementation on production performance, digestibility and dietary AME content. Animal Feed Science and Technology 110, 185-200. doi:10.1016/S0377-8401(03)00218-9
Sugiharto S, Ranjitkar S (2019) Recent advances in fermented feeds towards improved broiler chicken performance, gastrointestinal tract microecology and immune responses: a review. Animal Nutrition 5, 1-10. doi:10.1016/j.aninu.2018.11.001

Vig AP, Walia A (2001) Beneficial effects of Rhizopus oligosporus fermentation on reduction of glucosinolates, fibre and phytic acid in rapeseed (Brassica napus) meal. Bioresource Technology 78, 309-312. doi:10.1016/S0960-8524(01)00030-X

Walters HG, Coelho M, Coufal CD, Lee JT (2019) Effects of increasing phytase inclusion levels on broiler performance, nutrient digestibility, and bone mineralization in low-phosphorus diets. Journal of Applied Poultry Research 28, 1210-1225. doi:10.3382/japr/pfz087

Woyengo TA, Guenter W, Sands JS, Nyachoti CM, Mirza MA (2008) Nutrient utilisation and performance responses of broilers fed a wheatbased diet supplemented with phytase and xylanase alone or in combination. Animal Feed Science and Technology 146, 113-123. doi:10.1016/j.anifeedsci.2007.11.013

Wu YB, Ravindran V, Thomas DG, Birtles MJ, Hendriks WH (2004) Influence of phytase and xylanase, individually or in combination, on performance, apparent metabolisable energy, digestive tract measurements and gut morphology in broilers fed wheat-based diets containing adequate level of phosphorus. British Poultry Science 45, 76-84. doi:10.1080/00071660410001668897

Xu FZ, Zeng XG, Ding XL (2012) Effects of replacing soybean meal with fermented rapeseed meal on performance, serum biochemical variables and intestinal morphology of broilers. Asian-Australasian Journal of Animal Sciences 25, 1734-1741. doi:10.5713/ajas. 2012.12249

Zaworska A, Kasprowicz-Potocka M, Frankiewicz A, Zduńczyk Z, Juśkiewicz J (2016) Effects of fermentation of narrow-leafed lupine (L. angustifolius) seeds on their chemical composition and physiological parameters in rats. Journal of Animal and Feed Sciences 25, 326-334. doi: $10.22358 / \mathrm{jafs} / 67804 / 2016$

Zaworska A, Frankiewicz A, Kasprowicz-Potocka M (2017) The influence of narrow-leafed lupin seed fermentation on their chemical composition and ileal digestibility and microbiota in growing pigs. Archives of Animal Nutrition 71, 285-296. doi:10.1080/1745039X. 2017.1329130

Handling editor: Velmurugu (Ravi) Ravindran 